\title{
Long Distance Parenting in Early Childhood
}

\author{
Ice Purnawanti Puspitasari ${ }^{1, *}$, Yeni Rachmawati ${ }^{2}$, Ica Purnamasari ${ }^{3}$ \\ ${ }^{1,2}$ Early Childhood Education, Indonesia University of Education, Bandung, Jawa Barat 40154, Indonesia \\ ${ }^{3}$ Non Formal Education, Malang State University, Malang, East Java, Indonesia \\ *Corresponding author. Email: icepurnawantipaud@upi.edu
}

\begin{abstract}
Parenting style is a main factor in stimulating the aspects of children's growth and development since their early childhood. Parents are expected to live together and cooperate with each other in taking care and educating their children. However, parents with Long Distance Relationships have changed their parenting style due to several factors, namely demands of economic needs, career, and education. These factors have forced them to live apart from their children but they are demanded to keep playing their role as parents. This study aims at describing the importance of parenting style for early childhood implemented by parents in a Long Distance Relationship (LDR). This study employed library research design by studying numerous literatures. The result of this study is expected to be significantly used as reference for parents in a Long-Distance Relationship (LDR) to gain information regarding the importance of parenting style for early childhood.
\end{abstract}

Keywords: Early Childhood, parenting, parents with long distance relationship (LDR).

\section{INTRODUCTION}

Parenting is a media for parents to interact with their children by taking care of, guiding, teaching and educating their children so that they have good quality and independence in the future [1]. It is because the most prior education received by children is from their parents [2]. Both parents should live together and be cooperative in educating, caring for and stimulating all aspects of children's growth and development [3]. Nevertheless, numerous factors such as economic, career, education level and prestige, can force a parent to live separately or to be in a Long Distance Relationship. Parents who are in this situation usually encounter various problems including distance to look after, guide and stimulate their children's development, and lack of communication, when in fact, children need optimal attention and affection from their parents [4].

Parents in Long Distance Relationships have a lack of time to gather and cooperate [5]. This situation forces one of the parents (father) as the head of the family to not be able to do his role properly [6]. In general, parents live with Long Distance Relationships because they tend to maintain their job or career. In terms of educating, taking care and stimulating children's development, living with a Long Distance Relationship is not as easy as living together [7].

The parenting style applied by one parent will be different from other parents because they have their own habits or model in instilling values and stimulating all aspects of child development [8]. Parenting that is applied by parents is very essential for the children's future [9]. The success and achievements achieved by a child are not only seen from the quality of educational institutions but also from how parents prepare for their child's education that is being pursued or further education.

This article specifically discusses the importance of parenting style for parents in a long distance relationship parenting (LDR). This discussion is supported by a literature review that begins with an understanding of how important parenting styles are and the concept of parents with a long distance relationship (LDR).

The structure of this article is as follows: Part 1 is an Introduction. Part 2 describes the importance of parenting in stimulating children's growth and development. Part 3 is about parents with Long Distance Relationships who must keep applying the best parenting style and playing their roles as parents. Part 4 is the Conclusion.

\section{PARENTING STYLES}

The importance of parenting style in stimulating early childhood development and growth is because parenting is one of the significant and main factors in determining the future of children to face future lives independently and to be able to solve problems that will be encountered in the future. Parents are the most important educators for 
their children [10]. The role of both parents is very fundamental as an example that will be imitated by children. An early age (0-6 years) is very decisive and cannot be ignored by both parents, early childhood is a very important stage because this is a critical and strategic period in the process of child growth and development [11]. Thus, parents have the obligation to care for, raise, educate, provide protection and welfare in increasing the ability and quality of children during their growth and development so that it can prevent neglect and unfair treatment for children, because the child's future is very dependent on the experience that has been passed, parenting and educational factors besides other factors [12]

Parenting is an interaction between parents and children, including: taking care for their children, educating, instilling morals, protecting, feeding, cleaning, introducing and practicing social life so they can be accepted by society. [13] Parenting style can be influenced by various factors, namely:

\section{Parents' Personality}

Every parent is different and has a different level of maturity, education, intelligence, energy, patience and attitude. These variables may affect the level of sensitivity of parents to children's needs, expectations of themselves and the child, and the ability of parents to apply their role as models for their children.

\section{Parents' Development History}

The experiences gained in childhood can affect the parenting style applied to their children; both the experiences gained through the direct learning process or the parenting patterns received in childhood can affect the social and emotional development of these parents. For example, in childhood, the parents received a very strict discipline, it probably would be applied by the parents to their children as well [14].

\section{Parents' Belief}

The parents' belief is an important element that will influence the parenting model because beliefs have been instilled in parents from an early age (0-6 years) or throughout life.

\section{Parents' Knowledge}

Parents have knowledge about children's development through various sources including education, books, people (society), and experiences with children. From the experience gained, parents can apply the best parenting styles for their children.

\section{Gender}

The abilities and attitudes between men and women will differ when raising children. These differences do not determine right or wrong, wise or more experienced in applying parenting to children. Fathers put more emphasis on the independence of their children. While, mothers tend to take care, cultivate, and always want to be close to their children.

Proper parenting can stimulate optimal early childhood development and growth, including:

1. Can develop children's praiseworthy, kindness, politeness and moral character [15].

2. Can develop children's personality, and improve brain intelligence [16].

3. Can enhance children's social intelligence [17].

4. Can build a positive childhood independence [18].

5. Can improve early childhood emotional intelligence [19].

Both parents are required to know and understand and work cooperatively to determine the best parenting styles for their children at their childhood so that the goals of children's growth and development can be stimulated properly and raise qualified children in the future.

\section{LONG DISTANCE PARENTING}

Parents are one of the components in the family through the marriage bond. In a family, parents are responsible for taking care, educating, guiding, and stimulating all aspects of their children's development. Family is the smallest organization that is bound by blood, marriage, lives together and has respective roles and functions [20]. Working together and living in one house in educating, taking care, and stimulating children's development and growth will create a conducive environment and harmonious family atmosphere. However, the level of economic, career, prestige, and education force parents to live separately for certain periods of time to meet family needs. Parents who are forced to live long distance must understand that distance is one of the problems that must be faced and parents should be aware of their respective roles so that the development and growth of children can be stimulated optimally and the harmony and intimacy of the family will be maintained. [21].

There are three categories of Long-Distance Relationship (LDR), namely [22]:

1. The category of long-term separation: less than 6 months, 6 months, or more than 6 months.

2. The category of meeting: once a week, one week, one month less than one month.

3. The category of distance: less than 2-294 miles, more than 250 miles.

Long Distance Relationship (LDR) is a situation where parents and child live apart so that they cannot meet at any time. However, parents should properly do parenting and play their roles as parents. 
There are several roles of parents that must be manifested, namely [23]:

1. Meet the primary needs namely, food, shelter and clothing.

2. Provide emotional support (secondary needs).

3. Give protection.

4. Give education.

5. Encourage children to always be independent.

6. Play as a role model

7. Introduce and teach children about social norms.

Each parent has a different way and style of parenting [24]. There are three ways of parenting such as authoritarian, permissive, and or authoritative parenting. Authoritarian parenting is about being strict parenting which is identical to regulation and demands children. It may cause children not to respond to their wishes properly. Authoritarian parenting is also characterized by parents who do not provide space for children to express their opinions or wishes, they tend to give punishment and demand children to always obey what parents ordered [25]. There are four characteristics of authoritarian parenting, namely:

1. Parents tend to regulate, control, and give a warning if the child's behaviour is not appropriate with the rules they made.

2. Parents give rules based on values, and traditions that they think are best.

3. Parents want their children to obey the rules without thinking about their feelings.

4. Parents do not provide opportunities for children to be independent.

Permissive parenting is a parenting style for parents that allows them to do something, indulge, and let their children make mistakes. There are two developments in permissive parenting, namely (1) parents assume that the child has the right to determine his / her wishes, does not interfere, does not demand much, and parents always provide warmth and respond to children (2) parents are lack of knowledge of children's rights, however parents do not fully understand the child's behaviour, so that parents do not pay attention and do not care about their child's behaviour. The characteristics of permissive parenting are:

1. Parents always give space for their children to make decisions and do things.

2. Parents make few rules.

3. Parents do not force children to do good behaviour.
4. Parents always fulfil all the children's wishes.

Authoritative parenting is a parenting style that provides directions for children to be independent, while still limiting and controlling children's behaviour by means of deliberation and full affection. The characteristics of authoritative parenting are:

1. Parents provide clear rules and hope that children have mature behaviour.

2. Parents will give punishment if the child breaks the rules, if necessary.

3. Parents provide encouragement and freedom to children.

4. Parents listen, review, and provide suggestions for children's opinions so that they have open communication.

5. Parents recognize the rights of parents and children.

The three parenting styles will greatly affect the growth and development of children from their early childhood to adulthood. Thus, every parent must apply the most appropriate parenting style for their children.

\section{CONCLUSION}

Parents with long distance relationships (LDR) must keep cooperating in implementing proper parenting styles for their children's early childhood growth and development can be optimally stimulated. Parenting is an important factor in addition to other factors to stimulate development and growth in early childhood. Both parents must know and understand the parenting styles that they apply to their children because education is initially and mainly obtained by children from parents. The parenting style applied by each parent will be different based on the experience, understanding, and education that the parents have received.

There are several parenting styles that are often applied, namely authoritative parenting that is characterized by parents who always guide, provide input and give freedom to children before carrying out an activity independently. Authoritarian parenting is a parenting style that tends to be dominated by parents and tends to force children to follow their orders. Permissive parenting is a parenting style that pampers children with love, but parents rarely give rules.

\section{REFERENCES}

[1] Agustiawati I. Pengaruh pola asuh orang tua terhadap prestasi belajar siswa pada mata pelajaran akuntansi kelas XI IPS di SMA Negeri 26 Bandung (Doctoral dissertation, Universitas 
Pendidikan Indonesia). 2014. Available from: http://repository.upi.edu/12418/.

[2] Anisah AS. Pola asuh orang tua dan implikasinya terhadap pembentukan karakter anak. Jurnal Pendidikan UNIGA. 2017;5(1):70-84.

[3] Inten DN. Penanaman kejujuran pada anak dalam keluarga. FamilyEdu: Jurnal Pendidikan Kesejahteraan Keluarga. 2017;3(1):1-10. Available from: https://ejournal.upi.edu/index.php/ familyedu/article/view/5907.

[4] Primasari DA. Kehidupan keluarga long distance marital in relationships [Doctoral dissertation, Universitas Airlangga]; 2015. Available from: http://repository.unair.ac.id/39307/.

[5] Ramadhini S, Hendriani W. Gambaran trust pada wanita dewasa awal yang sedang menjalani long distance marriage. Jurnal Psikologi Klinis dan Kesehatan Mental. 2015;4(1):15-20. Available from: http://journal.unair.ac.id/downloadfullpapers-jpkk869db9c43ffull.pdf.

[6] Janssens A, Goossens L, Van Den Noortgate W, Colpin H, Verschueren K, Van Leeuwen K. Parents' and adolescents' perspectives on parenting: Evaluating conceptual structure, measurement invariance, and criterion validity. Assessment. 2015;22(4):473-89. Available from: https://doi.org/10.1177/1073191114550477.

[7] Handayani Y. Komitmen, conflict resolution, dan kepuasan perkawinan pada istri yang menjalani hubungan pernikahan jarak jauh. Psikoborneo: Jurnal Ilmiah Psikologi. 2016;4(3):1-9. Available from: http://e-journals.unmul.ac.id/index.php/ psikoneo/article/view/4090.

[8] Jatmikowati TE. Efektifitas komunikasi orang tua terhadap kepribadian intrapersonal anak. Pedagogi: Jurnal Anak Usia Dini dan Pendidikan Anak Usia Dini. 2018;4(2):1-5. Available from: http://journal.umsurabaya.ac.id/index.php/Pedagogi /article/view/1936.

[9] Bibi F, Chaudhry AG, Awan EA, Tariq B. Contribution of parenting style in life domain of children. IOSR Journal of humanities and social science (IOSR-JHSS). 2013;12(2):91-5.

[10] Kusumaningtyas K. Faktor pendapatan dan pendidikan keluarga terhadap perkembangan motorik halus anak usia 3-4 tahun. Jurnal Penelitian Kesehatan. Suara Forikes: Journal of Health Research Forikes Voice. 2016;7(1):1-11. Available from: http://dx.doi.org/10.33846/ sf.v7i1.13.

[11] Gustian D. Pola asuh anak usia dini keluarga muslim dengan ibu pekerja pabrik. Ta'dib: Jurnal Pendidikan Islam. 2018;7(1):370-85. Available from: https://doi.org/10.29313/tjpi.v7i1.3532.
[12] Achmad IF, Latifah LH, Dewi N. Hubungan tipe pola asuh orang tua dengan emotional quotient (EQ) pada anak usia prasekolah (3-5 tahun) di TK Islam Al-Fattaah Sumampir Purwokerto Utara. Jurnal Keperawatan Soedirman. 2010;5(1):47-57.

[13] Adawiah R. Pola asuh orang tua dan implikasinya terhadap pendidikan anak: Studi pada masyarakat dayak di Kecamatan Halong Kabupaten Balangan. Jurnal Pendidikan Kewarganegaraan. 2017;7(1):3348. Available from: http://dx. doi.org/10.20527/kewarganegaraan.v7i1.3534.

[14] Martin, Carole A \& Colbert, Karen K. Parenting a life span perspective. New York: McGraw- Hill Book Company; 1997.

[15] Rosmiati A. Teknik stimulasi dalam pendidikan karakter anak usia dini melalui lirik lagu dolanan. Resital: Jurnal Seni Pertunjukan (Journal of Performing Arts). 2014;15(1):71-82. Available from: https://doi.org/10.24821/resital.v15i1.801.

[16] Vinayastri A. Pengaruh pola asuh (parenting) orangtua terhadap perkembangan otak anak usia dini. Jurnal Ilmiah Widya, 2015;1(1):1-10.

[17] Robbiyah REkasari D, Witarsa R Pengaruh pola asuh ibu terhadap kecerdasan sosial anak usia dini di TK Kenanga Kabupaten Bandung Barat. Jurnal Obsesi: Jurnal Pendidikan Anak Usia Dini. 2018;2(1):76-84.

[18] Komala K. Mengenal dan mengembangkan kemandirian anak usia dini melalui pola asuh orang tua dan guru. Tunas Siliwangi: Jurnal Program Studi Pendidikan Guru PAUD STKIP Siliwangi Bandung. 2015;1(1):31-45.

[19] Fitriani L. Peran pola asuh orang tua dalam mengembangkan kecerdasan emosi anak. Lentera. 2015;17(1):93-110.

[20] Purnamasari I. Interaksi keluarga jarak jauh menggunakan smartphone di kota Tarakan Provinsi Kalimantan Utara. Jurnal Pendidikan dan Pemberdayaan Masyarakat (JPPM). 2020;7(1):58-67.

[21] Zakiyah RU, Nuraeni E. Pola pemenuhan hak dan kewajiban suami istri long distance relationship (ldr) di Desa Batujaya, Karawang. Al-Ahwal AlSyakhsiyyah: Jurnal Hukum Keluarga dan Peradilan Islam. 2020;1(2):65-178.

[22] Primasari, Devi A. Kehidupan keluarga "long distance marital in relationship". Dialektika. 2018;13(1):96-102.

[23] Jailani M, Syahran. Teori pendidikan keluarga dan tanggung jawab orang tua dalam pendidikan anak usia dini. Nadwa. 2014;8(2):245-60.

[24] Indrawati D, Puspita LM, Murdani I, Gusti A. Hubungan pola asuh orang tua dengan kemampuan sosialisasi pada anak usia 4-5 tahun di TK Negeri Tabanan [Bachelor thesis, Universitas Udayana]; 2016.

[25] Santrock JW. Life span development. Jakarta: Erlangga; 1995. 